\title{
Impact of Rainfall Variability on Crop Production within the Worobong Ecological Area of Fanteakwa District, Ghana
}

\author{
Conrad Kyei-Mensah, ${ }^{1}$ Rosina Kyerematen ${ }^{(D)},{ }^{2}$ and Samuel Adu-Acheampong ${ }^{3}{ }^{3}$ \\ ${ }^{1}$ Climate Change and Sustainable Development, University of Ghana, Ghana \\ ${ }^{2}$ Department of Animal Biology and Conservation Science, P.O. Box LG 59, University of Ghana, Ghana \\ ${ }^{3}$ Agronomy Department, University for Development Studies, P.O. Box TL 1882, Nyankpala, Tamale, Ghana \\ Correspondence should be addressed to Rosina Kyerematen; rkyerematen@ug.edu.gh
}

Received 12 February 2019; Revised 6 April 2019; Accepted 11 April 2019; Published 2 May 2019

Academic Editor: Christos Tsadilas

Copyright (C) 2019 Conrad Kyei-Mensah et al. This is an open access article distributed under the Creative Commons Attribution License, which permits unrestricted use, distribution, and reproduction in any medium, provided the original work is properly cited.

\begin{abstract}
Crop production in the Fanteakwa District is predominantly rainfed, exposing this major livelihood activity to the variability or change in rainfall pattern. The net potential effect of severe changes in rainfall pattern is the disruption in crop production leading to food insecurity, joblessness, and poverty. As a major concern to food production in Ghana, this study seeks to show the relationship between the production of major crops and rainfall distribution pattern in the Worobong Agroecological Area (WAA) relative to food security in the face of climate change. The study analysed the variability in local rainfall data, examining the interseasonal (main and minor) rainfall distribution using the precipitation concentration index (PCI), and determined the pattern, availability of water, and the strength of correlation with crop production in the WAA. Data from the Ghana Meteorological Agency (GMet) spanning a 30-year period and grouped into 3 decades of 10 years each was used. Selected crop data for 1993-2014 was also obtained from the Ministry of Food and Agriculture's District office and analyzed for trends in crop yield over the period and established relationship between the crop data and the rainfall data. Part of the result revealed that rainfall variability within the major seasons in the 3 groups was lower than the minor seasons. It further showed that yields of three crops have declined over the period. Among the strategies to sustain crop production is to make the findings serve as useful reference to inform discussions and policy on adaptive agricultural production methodologies for the area in the face of changing climate.
\end{abstract}

\section{Introduction}

Poor communities in developing economies mainly depend on climate-sensitive activities such as agriculture for their livelihood and are particularly vulnerable to climate change [1-5]. It has been reported that nearly three in four people living in rural Africa and other developing countries are dependent on agriculture in one way or another [6]. Also, it is estimated that climate change will cause a direct reduction in real household consumption by $5-10 \%$ in 2050 and a reduction in real gross domestic production of 1.9$7.2 \%$ in Ghana $[7,8]$. For instance, it has been reported that rainfall variability affects the production of traditional crops, increases crop diseases incidents, and causes drastic reductions in soil fertility [9-12]. Additionally, analysis of recent rainfall conditions in West Africa suggests long-term change in rainfall pattern within the semiarid and subhumid zones $[13,14]$. Also, the mean number of rainy days has significantly reduced throughout the different seasons in West Africa [15].

The impact of rainfall on crop production has been assessed differently by various authors in the subhumid areas. Among these methods are intraseasonal, interseasonal, and annual rainfall variability [16]. Owusu and Waylen [17] employed intraseasonal and interannual variability methods to monitor rainfall patterns in rainy seasons in the subhumid areas of Africa to assess the potential threat of rainfall variability to food security, although the number of years of rainfall record that is necessary to detect any significant trends in rainfall in arid and semiarid regions is quite debatable $[10,11,18]$. However, there is a substantial evidence of adverse impact of change in seasonal or annual rainfall 
patterns on the production of some major cereals [19-22]. Also, it has been reported in other parts of the world that climate variability and/or change have been attributed to changes in production or will be responsible for future change in production dynamics [23-26]. Bewket [19] reported short rainy seasons (March-May) and much more variable rainfall periods between June and September.

A major natural occurrence which is also indispensable in food production especially in the developing world is rainfall. More than 60 percent of staple foods are produced from rainfed agriculture which is practiced by more than $80 \%$ and $90 \%$ of global and African communities, respectively [2729]. Rainfed agriculture accounts for a large percentage of the total crop production especially rural areas in Ghana [6]. For instance, cocoa production which contributes a substantial amount to the Gross Domestic Product (GDP) of Ghana is almost entirely dependent on rainfall $[6,30]$. Also, most of the major food crops are produced through rainfed agriculture. Rainfed agriculture thus became the main water supply system for the majority of food or crop production in Ghana $[4,6]$.

The threat of food insecurity has increased as a result of the phenomenon of climate change and variability among many farming communities [13,31, 32]. Climate change and variability is arguably the most debated scientific phenomenon in recent literature $[33,34]$. Although these debates are highly controversial, there is a broad consensus that climate change has happened and still ongoing process although there are disagreements over the major cause as natural or anthropogenic [33-36]. An empirical evidence that there is an ongoing climate change especially in sub-Saharan Africa is the receding ice on Mount Kilimanjaro [37]. Among the most vulnerable ventures that can also have major food security implications is the impact of climate change or variability of agricultural production [10,11]. For instance, it has been reported that maize yield in Ghana is expected to reduce by about 20 percent by 2050 due to climate change [6].

Agriculture is reported to be a major source of livelihood to a large number of Ghanaians where small-scale farming accounts for $80 \%$ of domestic production [38]. The sector employs close to $60 \%$ of the formal and informal labour force. On the average, agriculture contributes about $30 \%$ of the Gross Domestic Product (GDP) of Ghana [6]. In terms of production practices in Ghana, the main method used is rainfed, with only $0.2 \%$ of practiced irrigation [39]. As a result, seasonal rainfall variability has a profound effect on soil water availability especially for crop production. In recent times, changes in rainfall distribution, interseasonal fluctuations, and erratic rainfall patterns have been reported to have resulted in reductions in crop production which has become a major issue to farmers and policy-makers as threats to food security as reported elsewhere [11, 13, 2426]. This is especially so for the major crops produced in Ghana, namely, cassava, cocoyam, plantain, and tomatoes [39]. Although current cassava production outputs show increasing trends, climate change scenarios in the future predict yield reductions of cassava and cocoyam by $3 \%$, $11 \%$, and $13.5 \%$ and $29.6 \%, 53 \%$, and $68 \%$ by 2020,2050 , and 2080, respectively [40, 41]. Also, more recent statistical evidences show that interannual variability has increased within the major and minor rainy seasons, while the minor rainy seasons have become much drier and shorter (GMet) even though the report provides very little details on specific localities where these trends were observed including major crop producing areas which includes the WAA of the semideciduous areas of Ghana. WAA constitutes a unit in developing a national map for agricultural performance in climate variability or change and for decision-making in resolving challenges within the agricultural sector of the semideciduous areas which have rarely been studied relative to climatic variability. This study analysed the variability in local rainfall data, examined the interseasonal (main and minor) rainfall distribution for trends, and determined the pattern and strength of correlation with crop production in WAA to serve as future reference as well as engender policy discussions on agriculture production strategies for the area in the face of changing climate.

\section{Method}

2.1. Study Area. Fanteakwa District is in the Eastern Region of Ghana, with Begoro as its capital. The district lies within longitude $0^{\circ} 32.5$ west and $0^{\circ} 10$ east and latitude $6^{\circ} 15$ north and $6^{\circ} 40$ north (Figure 1). It is bordered to the north by the Volta Lake, north-west by Kwahu South District, southwest by East Akim District, east by Manya Krobo, and southeast by Yilo Krobo District. The district has a total land area of $1,150 \mathrm{~km}^{2}$ with cultivable land area of 76,133 Ha. The district is endowed with large tracks of arable land suitable for cultivating cocoa, cereals, root crops, vegetables, plantain, banana, and yam. Land in the forest belt is fertile for cultivation of crops [41].

2.2. Data Collection and Analysis. We studied rainfall records from the Ghana Meteorological Agency (GMet), spanning a thirty-year period, from 1985 to 2014 . Additionally, time series data on cocoyam, plantain, cassava, and tomato production and yield from MoFA for a 12-year period (20032014) was used. This data was used to establish trends in interannual rainfall distribution and interseasonal one (i.e., major and minor seasons) for the above-mentioned 30year period, while assessing the pattern in annual rainfall distribution and crop yield over the already mentioned 12year period. Our analysis was due to limited data from MoFA in the Fanteakwa district.

2.3. Models for Rainfall and Crop Assessment. In earlier assessment and rainfall impact studies on crop production, predictive models and forecasts have dominated literature. Ecophysiological model provides the aggregation of diverse components such as rainfall data and agronomic information to forecast how a particular plant will respond to different environments [42]. Ricardian or cross-sectional approach $[43,44]$ is a similar model which is linked closely to a correlation between how potentially viable a particular land is and the existing agroclimatic conditions. To understand the current relationships of rainfall and crop production, the 


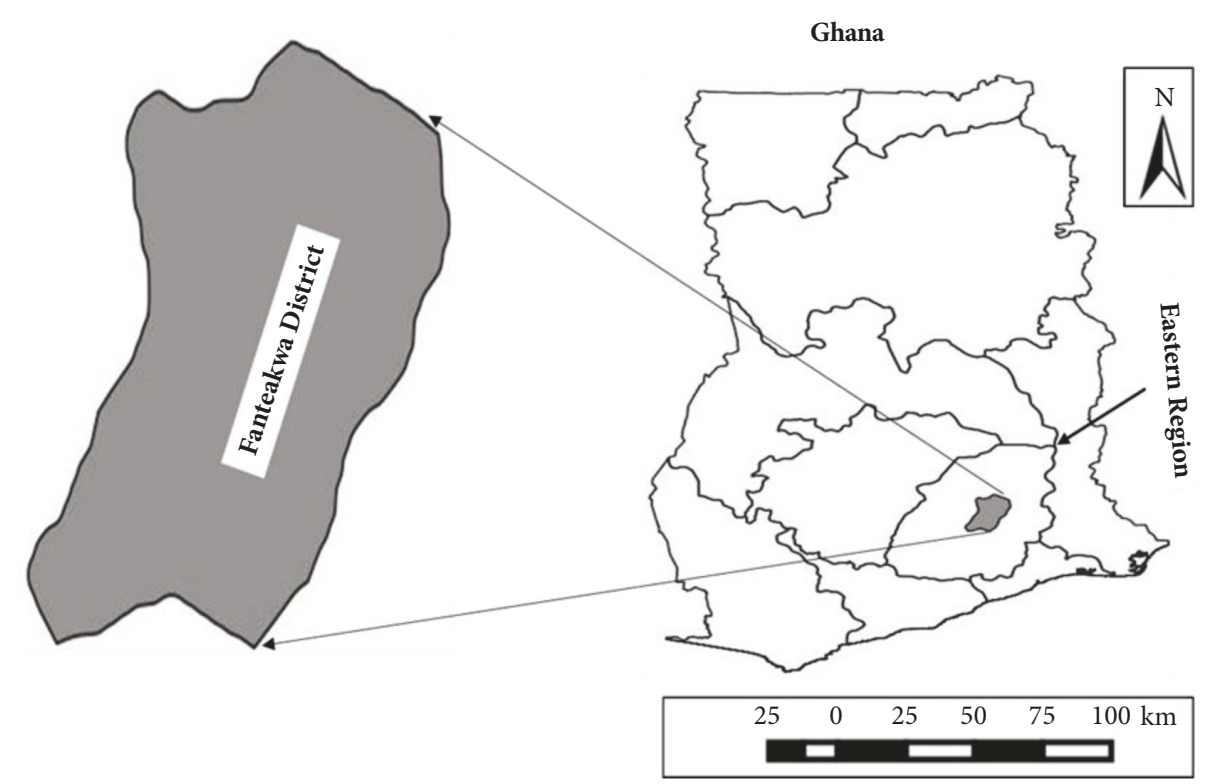

FIGURE 1: A map of Ghana showing Fanteakwa district in the Eastern Region of Ghana.

Pearson product moment correlation coefficient was used to generate statistical indices, while analysis of the interannual and interseasonal rainfall variability was done using coefficient of variation (CV) and precipitation concentration index (PCI) [45]. The PCI was used for this study because it has been the choice of model in recently published works on analysing rainfall variability and also due to its high ability to measure temporal variations in rainfall [46-50]. Most importantly, the PCI has the ability to describe how rainfall is distributed yearly (i.e., whether it is evenly distributed or concentrated in a single month), an attribute considered for this study. Beside PCI, there are other rainfall variability measures such as the precipitation concentration period (PCP), fulcrum (centre of gravity), and precipitation concentration degree (PCD) that can equally perform well [51-53]. Other methods such as Fournier Index for year (FI), Modified Fournier Index for year (MFI), and the Modified Fournier-Maule Index for year measure rainfall aggressiveness, which was not an attribute considered in this study [47].

2.4. Crops Output and Rainfall Relationship. We assessed annual crop yield for cassava, cocoyam, plantain, and tomatoes for the period 2003-2015 and rainfall data for 2003-2014. The discrepancy of applying a standardized period between the two data sets is attributed to gaps in the production crop data. To this extent, the period between 2003 and 2014, spanning eleven years of rainfall and crop production relationship and trends, was cautiously used. The two data sets were subjected to bivariate correlation and cross tabulation analysis to determine the impact of rainfall variability on change in crop production. For a minimal effect, the study analysed an annual average temperature over a period of 35 years (1980-2015) in some instances and 27 years (1980-2007) in the Worobong area that showed two outputs of minimum and maximum levels. Results from questionnaires that were administered and information from MoFA in the Fanteakwa district show that cropping systems and agronomic practices remained basically the same or constant in the period that the data was taken (i.e., number of planted seeds per stand, quantity and type of fertilizer applied, weed and pest control measures, etc.) in those farms used for data collection.

\section{Results}

3.1. Seasonal Rainfall Variability. Analysis of monthly rainfall data from GMet between 1985 and 2014 established a pattern of variability. Three data sets, described as Climate Assessment Decade (CAD), of 10 years, ranging from 1985 to 1994, 1995 to 2004, and 2005 to 2014, were categorised to allow comparison of variation in rainfall distribution in the area. As the area experiences a bimodal rainfall regime, the CAD for each data set is further grouped into the major season, between March and July, and minor season, between September and November. This grouping was intended to examine the comparative basis for the extent of variability. The result shows a trend in seasonal (major and minor) variability in rainfall distribution (Figure 2). The major season for the first decade under consideration (1985-1994) recorded an average rainfall of $1449.94 \mathrm{~mm}$ compared to the third decade (19952004) which recorded a significantly lower rainfall (1278.58 $\mathrm{mm}$ ) and $1098.94 \mathrm{~mm}$ between 2005 and 2014. In other words, there was a decrease in rainfall distribution in the major seasons over the 30-year period. Similarly, the minor season for each CAD recorded increased variability (Figures 2 and 3), $1374.98 \mathrm{~mm}, 967.50 \mathrm{~mm}$, and $1117.82 \mathrm{~mm}$ for 1985-1994, 19952004, and 2005-2014, respectively, with the highest incidence of variability observed in the first and second decades of the period under consideration.

The result from the coefficient of variation (CV) of the major and minor seasons of the three decades showed 



FIGURE 2: Annual average rainfall for major and minor seasons for three separate decades of 1985-1994, 1995-2004, and 2005-2014 within the Fanteakwa District, Ghana. Source: GMet, 2017.



FIGURE 3: Selected crops yield between 2003 and 2015 within the Fanteakwa District of Ghana. Source: MoFA-Begoro, 2016.

significant variation in both seasons with the highest in the minor season ( $\mathrm{CV}, 5.7 \%$ ) compared to the major (CV, 7.6\%). In effect, for the 30-year period (1984-2014), the total average rainfall amount reduced by $351 \mathrm{~mm}$ consistently for the major season and $267.16 \mathrm{~mm}$ in the minor season.

According to Oliver [45], PCI values for determining rainfall concentration are computed as PCI $=100 \times$ $\left\{\Sigma P_{\mathrm{I}}^{2} /\left(\Sigma \mathrm{P}_{\mathrm{I}}\right)^{2}\right\}$ where $\mathrm{P}_{\mathrm{I}}$ is the rainfall amount of the $\mathrm{X}^{\text {th }}$ (for each decade of both seasons) and $\Sigma$ is the summation of the three decades (30 years). He further evaluated the outcomes of PCI using the following indicators: values less than 10 suggest a uniform concentration; values between 11 and 20 indicate high concentration, while those above
21 are considered very high rainfall amounts. A value for both seasons at 33 indicates a high concentration of rainfall, thereby showing enough rainfall for crop production in the 3 decades although there was significant variability over the period.

The findings of the yearly crop output within the Fanteakwa agroecological zone showed a downward trend for all major crops considered except tomato (Figure 2). Cassava production in 2003 was about 14,000 $\mathrm{mt} /$ ha compared to cocoyam and plantain which recorded 10,000 mt/ha and $10,700 \mathrm{mt} / \mathrm{ha}$, respectively, over the same year. Just like cassava which has recorded some steady reduction from 2003 to 2015 with percentage declines of $16.7 \%$, cocoyam and 
plantain also recorded $17.3 \%$ and $10.1 \%$ over the same period, respectively. Tomatoes on the other hand recorded rather a steady increase of 3,650 mt/ha in 2003 to $6,620 \mathrm{mt} / \mathrm{ha}$ in 2015 and increase of $28.9 \%$ within the same period.

The Pearson product moment correlation coefficient analysis carried out for the major cultivated crops considered (cassava, cocoyam, plantain, and tomatoes) and two climatic variables (rainfall and temperature) revealed that rainfall negatively correlates with all crops, i.e., cassava (-0.466), cocoyam (-0.431), plantain $(-0.274)$, except tomatoes $(0.417)$ within the Fanteakwa District. Again, except tomatoes, none of the crop outcomes showed positive significance with the major and minor rainfall seasons; $\mathrm{P}<-0.283, \mathrm{P}<-0.41$ for cassava between 2003 and 2014 .

\section{Discussion}

There are visible changing trends in rainfall patterns for minor seasons spanning September to November at a higher rate than the main season in the three decades considered for our analysis in the study area. This corroborates the finding from previous study in Ghana [22]. Such a trend shows there is a relatively less amount of rain water for crop production in the minor season in relation to previous decades and also the major season. This study did not project detailed monthon-month comparison of the data; such an exercise would have provided for each season (major and minor) the actual rainfall amounts relative to the corresponding months in other CAD and their values to show extent of variability. This will further show the direct impact of monthly rainfall on agriculture for instance. In the absence of that, average yearly major and minor rainfall amount will also provide enough basis for assessing the effect of the variability on crop production in each CAD [20]. Temperature also plays a major role in determining the overall relationship between crop production and other factors such as soil, water, and technology [22-24, 53]. This observation formed the basis for recommending that a lot more effort must be done to improve crop production within the major season because of less rainfall variability compared to the minor season. This strategy can help increase crop production, food security, and availability even as production in the minor season reduces. Although the calculated PCI values states a very high rainfall concentration in the two seasons, the variability within the season was also revealed by the coefficient of variation and mean values. There were no statistically tested and proven reasons for an increase in tomato production although all other crops produced in the area suffered production loss due to climate change. The immediate speculated reason for this increase could be the use of irrigation facilities during the off-production season [personal observation], but no study has been conducted to verify this assumption. The use of irrigation facilities in crop production especially vegetable production is known to increase production. For instance, crop yields increased up to $43 \%$ in smallholder farms in rural Ethiopia with the use of irrigation facility for production [54]. Other studies in Ghana have all indicated increases in crop yields under irrigation [55-57]. Although there seems to be a correlation between irrigation and increased production in tomato even under climate change situations even when other major crop yields are reducing, there could be other hidden reason(s) for why tomato production could go up in the study area. There is therefore the need for a thorough study on tomato production and climate variability in the study area and Ghana in general to find out these reasons for proper adaption measures to be taken.

\section{Conclusion}

Analysis of rainfall distribution and crop production could be done using several models for a relatively high-humid agroecological area. In this study, variation analysis of major and minor rainfall seasons showed variability in both seasons although it was relatively high in the latter season. Such differences in rainfall variability play a major role in crop production in the WAA where agriculture is generally rainfed. The high variability of rainfall in the minor season correlated with a reduction in crop production output. WAA has also recorded off-season tomatoes production through irrigation practices although the traditional crops; plantain, cocoyam, and cassava have all experienced steady declines. Attributing decline in yield solely to rainfall variability may not be accurate. Bad agricultural practices, nomadic herdsmen activities, and bushfires are analogous variables affecting crop production in the area. Nevertheless, our analysis showed a clear relationship between rainfall variability and crop production in our study area and also because production practices have not changed much over the period of study. To resolve rainfall challenge and sustain crop production in the area, piloting irrigation for selected crops, as some farmers are already doing, is highly recommended.

\section{Data Availability}

There was no other data used in this study apart from the one included in the manuscript and the supplementary materials (available here).

\section{Conflicts of Interest}

The authors declare that there are no conflicts of interest regarding the publication of this paper.

\section{Supplementary Materials}

Table S1: mean difference in rainfall between major and minor seasons in three separate decades, namely, 1985-1994, 19952004, and 2005-2014, within the Fanteakwa District of Ghana. Table 2: correlation analysis of climatic variability and crop yields between 2003 and 2014 within the Fanteakwa District in Ghana. (Supplementary Materials)

\section{References}

[1] Parry and Martin, Impacts, Adaptation and Vulnerability: Part of the Working Group II Contribution to the Fourth Assessment 
Report of the Intergovernmental Panel on Climate Change. Summary for Policymakers-A Report of Working Group II of the Intergovernmental Panel on Climate Change and Technical Summary-a Report Accepted by Working Group II of the IPCC But Not Approved in Detail, Cambridge University Press for the Intergovernmental Panel on Climate Change, 2007.

[2] P. K. Nath and B. Behera, "A critical review of impact of and adaptation to climate change in developed and developing economies," Environment, Development and Sustainability, vol. 13, no. 1, pp. 141-162, 2011.

[3] E. H. Allison, A. L. Perry, M.-C. Badjeck et al., "Vulnerability of national economies to the impacts of climate change on fisheries," Fish and Fisheries, vol. 10, no. 2, pp. 173-196, 2009.

[4] W. K. Dumenu and E. A. Obeng, "Climate change and rural communities in Ghana: Social vulnerability, impacts, adaptations and policy implications," Environmental Science \& Policy, vol. 55, pp. 208-217, 2016.

[5] K. R. Hope Sr., "Climate change and poverty in Africa," International Journal of Sustainable Development \& World Ecology, vol. 16, no. 6, pp. 451-461, 2009.

[6] G. T. Kwadz, J. K. Kuwornu, and I. S. Amadu, "Food crop farmers' willingness to participate in market-based crop insurance scheme: evidence from Ghana," Research in Applied Economics, vol. 5, no. 1, 2013.

[7] African Development Bank (AfDB), The Cost of Adaptation to Climate Change in Africa, 2011.

[8] G. C. Nelson, M. W. Rosegrant, J. Koo et al., "Climate change: impact on agriculture and costs of adaptation," International Food Policy Research Institute, vol. 21, 2009.

[9] J. J. Kashaigili, P. Levira, E. Liwenga, and M. V. Mdemu, "Analysis of climate variability, perceptions and coping strategies of tanzanian coastal forest dependent communities," American Journal of Climate Change, vol. 03, no. 02, pp. 212-222, 2014.

[10] J. E. Olesen, M. Trnka, K. C. Kersebaum et al., "Impacts and adaptation of European crop production systems to climate change," European Journal of Agronomy, vol. 34, no. 2, pp. 96112, 2011.

[11] P. Kurukulasuriya and S. Rosenthal, Climate Change and Agriculture: A Review of Impacts and Adaptations, 2013.

[12] C. Kyei-Mensah, Adoption of an Ecosystem-Based Adaptation (EbA) Approach in the face of Climate Change: Improving livelihoods in fringe communities around the Worobong South Forest Reserve [Doctoral thesis], University of Ghana, 2017.

[13] S. E. Nicholson, "Climatic and environmental change in Africa during the last two centuries," Climate Research, vol. 17, no. 2, pp. 123-144, 2001.

[14] C. Toulmin and B. Guèye, "Transformations in West African agriculture and the role of family farms," International Institute for Environment and Development, no. 123, 2003.

[15] F. Ndamani and T. Watanabe, "Influences of rainfall on crop production and suggestions for adaptation," International Journal of Agricultural Sciences, vol. 5, pp. 367-374, 2014.

[16] A. Ayansina and S. Ogunbo, "GIS approach in assessing seasonal rainfall variability in Guinea Savanna part of Nigeria," in Proceedings of the In 7th FIG regional conference, vol. 16, Vietnam, October 2009.

[17] K. Owusu and P. R. Waylen, "Identification of historic shifts in daily rainfall regime, Wenchi, Ghana," Climatic Change, vol. 117, no. 1-2, pp. 133-147, 2013.

[18] A. Y. Kwarteng, A. S. Dorvlo, and G. T. V. Kumar, "Analysis of a 27-year rainfall data (1977-2003) in the Sultanate of Oman,"
International Journal of Climatology, vol. 29, no. 4, pp. 605-617, 2009.

[19] W. Bewket, "Rainfall variability and crop production in Ethiopia: Case study in the Amhara region," in Proceedings of the In Proceedings of the 16th International Conference of Ethiopian Studies, vol. 3, pp. 823-836, Norwegian University of Science and Technology, Trondheim, Norway, 2009.

[20] D. B. Lobell, W. Schlenker, and J. Costa-Roberts, "Climate trends and global crop production since 1980," Science, vol. 333, no. 6042, pp. 616-620, 2011.

[21] J. Gornall, R. Betts, E. Burke et al., "Implications of climate change for agricultural productivity in the early twenty-first century," Philosophical Transactions of the Royal Society B: Biological Sciences, vol. 365, no. 1554, pp. 2973-2989, 2010.

[22] F. Y. Logah, E. Obuobie, D. Ofori, and K. Kankam-Yeboah, "Analysis of rainfall variability in Ghana," International Journal of Latest Research in Engineering and Computing, vol. 1, no. 1, pp. 1-8, 2013.

[23] R. Deihimfard, H. Eyni-Nargeseh, and A. Mokhtassi-Bidgoli, "Effect of future climate change on wheat yield and water use efficiency under semi-arid conditions as predicted by APSIMwheat model," International Journal of Plant Production, vol. 12, no. 2, pp. 115-125, 2018.

[24] L. Mumo, J. Yu, and K. Fang, "Assessing impacts of seasonal climate variability on maize yield in Kenya," International Journal of Plant Production, vol. 12, no. 4, pp. 297-307, 2018.

[25] Y. Wang, J. Zhang, G. Song, Z. Long, and C. Chen, "Impacts of recent temperatures rise on double-rice phenology across Southern China," International Journal of Plant Production, vol. 13, no. 1, pp. 1-10, 2019.

[26] Z. Wang, J. Chen, W. Tong, C. Xu, and F. Chen, "Impacts of climate change and varietal replacement on winter wheat phenology in the North China plain," International Journal of Plant Production, vol. 12, no. 4, pp. 251-263, 2018.

[27] J. Rockström, J. Barron, and P. Fox, "Water productivity in rainfed agriculture: challenges and opportunities for smallholder farmers in drought-prone tropical agroecosystems," Limits And Opportunities for Improvement, vol. 85, no. 669, pp. 1-8, 2003.

[28] FAO. Statistics (FAOSTAT, "FAO Statistics," URL, 2005, http://www.fao.org.

[29] S. P. Wani, J. Rockström, and T. Oweis, Rainfed agriculture: unlocking the potential, CABI, Wallingford, 2009.

[30] F. Asante and F. Amuakwa-Mensah, "Climate change and variability in Ghana: stocktaking," Climate, vol. 3, no. 1, pp. 7899, 2015.

[31] M. A. Akudugu, S. Dittoh, and E. S. Mahama, "The implications of climate change on food security and rural livelihoods: experiences from Northern Ghana," Journal of Environment and Earth Science, vol. 2, no. 3, pp. 21-29, 2012.

[32] P. Antwi-Agyei, A. J. Dougill, E. D. G. Fraser, and L. C. Stringer, "Characterising the nature of household vulnerability to climate variability: Empirical evidence from two regions of Ghana," Environment, Development and Sustainability, vol. 15, no. 4, pp. 903-926, 2013.

[33] D. Demeritt, "Science studies, climate change and the prospects for constructivist critique," Economy and Society, vol. 35, no. 3, pp. 453-479, 2006.

[34] R. A. Pielke Jr. and D. Sarewitz, "Bringing society back into the climate debate," Population and Environment, vol. 26, no. 3, pp. 255-268, 2005. 
[35] R. T. Watson, M. C. Zinyowera, R. H. Moss, and D. J. Dokken, "The Regional Impacts Climate Change: An Assessment of Vulnerability," IPCC Special Report, 2006.

[36] M. J. Mwandosya, "Mainstreaming Environment and Eliminate Change Concerns in National Planning in Tanzania," A paper presented at Development and Climate workshop Integrated Development and Climate policies: how to realize benefits at national and international level? Paris, France, 2006.

[37] H. Mongi, A. E. Majule, and J. G. Lyimo, "Vulnerability and adaptation of rain fed agriculture to climate change and variability in semi-arid Tanzania," African Journal of Environmental Science and Technology, vol. 4, no. 6, pp. 371-381, 2010.

[38] H. De Bon, L. Parrot, and P. Moustier, "Sustainable urban agriculture in developing countries. A review," Agronomy for Sustainable Development, vol. 30, no. 1, pp. 21-32, 2010.

[39] Ministry of Food and Agriculture, Agriculture in Ghana: Facts and Figures (2010). Statistic, Research and Information Directorate (SRID), 2011.

[40] P. Antwi-Agyei, Vulnerability and adaptation of Ghana's food production systems and rural livelihoods to climate variability, PhD Thesis of University of Leeds, 2012.

[41] Government of Ghana, The composite budget of the Fanteakwa District Assembly for the fiscal year 2016, Government of Ghana, 2019, https://www.mofep.gov.gh/sites/default/files/compositebudget/2016/ER/Fanteakwa.pdf.

[42] D. B. Lobell, M. B. Burke, C. Tebaldi, M. D. Mastrandrea, W. P. Falcon, and R. L. Naylor, "Prioritizing climate change adaptation needs for food security in 2030," Science, vol. 319, no. 5863, pp. 607-610, 2008.

[43] J. Kabubo-Mariara and F. K. Karanja, "The economic impact of climate change on Kenyan crop agriculture: A Ricardian approach," Global and Planetary Change, vol. 57, no. 3-4, pp. 319-330, 2007.

[44] R. Mendelsohn, W. D. Nordhaus, and D. Shaw, "The impact of global warming on agriculture: a Ricardian analysis," American Economic Review, vol. 84, no. 4, pp. 753-771, 1994.

[45] J. E. Oliver, "Monthly precipitation distribution: a comparative index," The Professional Geographer, vol. 32, no. 3, pp. 300-309, 1980.

[46] K. Khalili, M. N. Tahoudi, R. Mirabbasi, and F. Ahmadi, "Investigation of spatial and temporal variability of precipitation in Iran over the last half century," Stochastic Environmental Research and Risk Assessment, vol. 30, no. 4, pp. 1205-1221, 2016.

[47] J. Abolverdi, G. Ferdosifar, D. Khalili, and A. A. KamgarHaghighi, "Spatial and temporal changes of precipitation concentration in Fars province, southwestern Iran," Meteorology and Atmospheric Physics, vol. 128, no. 2, pp. 181-196, 2016.

[48] M. De Luis, J. C. González-Hidalgo, and L. A. Longares, "Is rainfall erosivity increasing in the Mediterranean Iberian Peninsula?" Land Degradation \& Development, vol. 21, no. 2, pp. 139-144, 2010.

[49] M. De Luis, J. C. González-Hidalgo, M. Brunetti, and L. A. Longares, "Precipitation concentration changes in Spain 1946-2005," Natural Hazards and Earth System Sciences, vol. 11, no. 5, pp. 1259-1265, 2011.

[50] M. Costea, "Using the Fournier indexes in estimating rainfall erosivity. Case study-the Secasul Mare Basin," Aerul si Apa. Componente ale Mediului, p. 313, 2012.

[51] M. A. A. Zarch, B. Sivakumar, and A. Sharma, "Droughts in a warming climate: a global assessment of Standardized precipitation index (SPI) and Reconnaissance drought index (RDI)," Journal of Hydrology, vol. 526, pp. 183-195, 2015.
[52] R. Valdés-Pineda, R. Pizarro, J. B. Valdés, J. F. Carrasco, P. García-Chevesich, and C. Olivares, "Spatio-temporal trends of precipitation, its aggressiveness and concentration, along the Pacific coast of South America (36-49 S)," Hydrological Sciences Journal, vol. 61, no. 11, pp. 2110-2132, 2016.

[53] M. F. Stuecker, M. Tigchelaar, M. B. Kantar, and V. Magar, "Climate variability impacts on rice production in the Philippines," PLoS ONE, vol. 13, no. 8, Article ID e0201426, 2018.

[54] Y. E. Ayalew, Irrigation, Food Production and Consumption Pattern in Smallholder Rural Households [Doctoral dissertation], Cornell University, 2009.

[55] E. Obuobie, B. Keraita, G. Danso et al., "Irrigated urban vegetable production in Ghana," Characteristics, Benefits and Risks, 2006.

[56] E. Bagson and C. J. W. Kuuder, "Assessment of a smallscale irrigation scheme on household food security and leisure in Kokoligu; Ghana," Research on Humanities and Social Sciences 3:1, 2013.

[57] E. Amankwah and T. O. Ocloo, "Contribution of small-scale irrigated agriculture to food security in the Upper West Region of Ghana," Journal of Developments in Sustainable Agriculture, vol. 7, no. 2, pp. 115-121, 2012. 


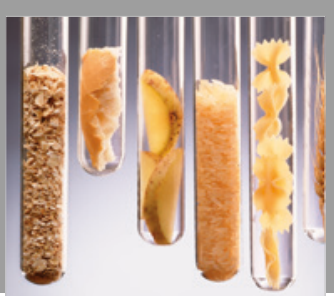

International Journal of Food Science

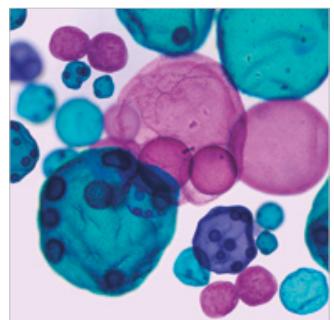

International Journal of Microbiology
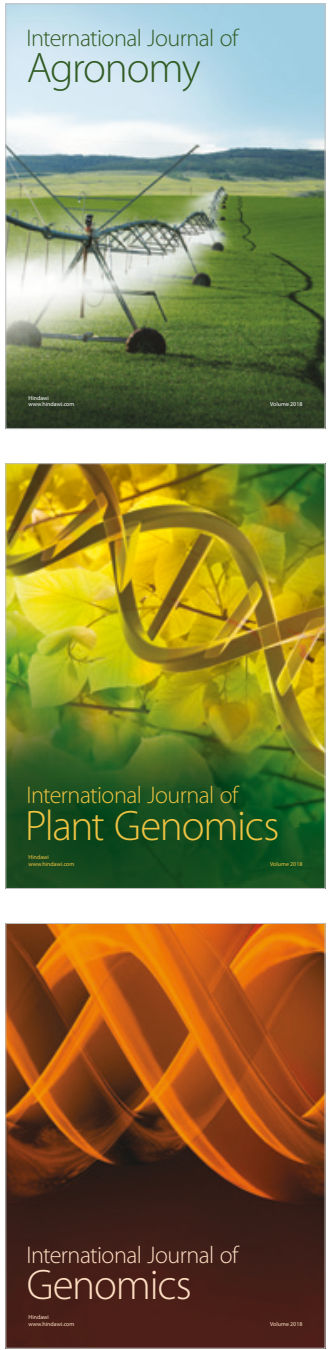

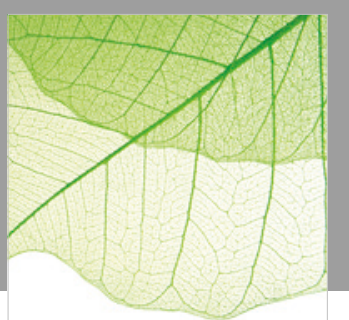

Journal of Botany
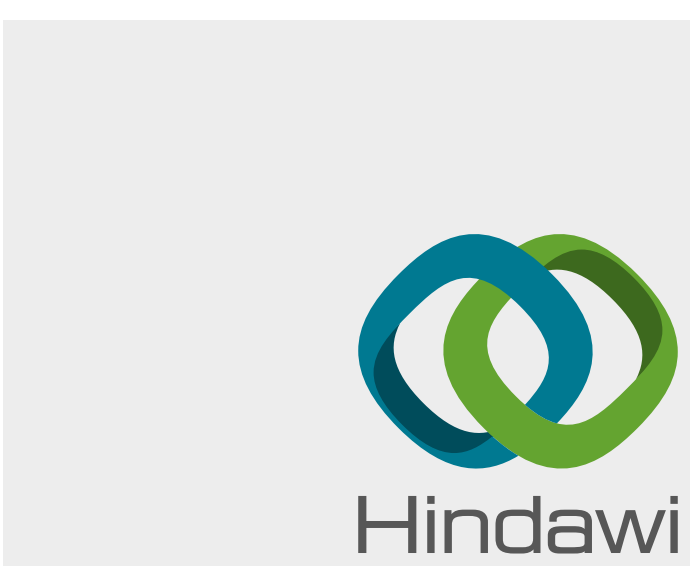

Submit your manuscripts at

www.hindawi.com
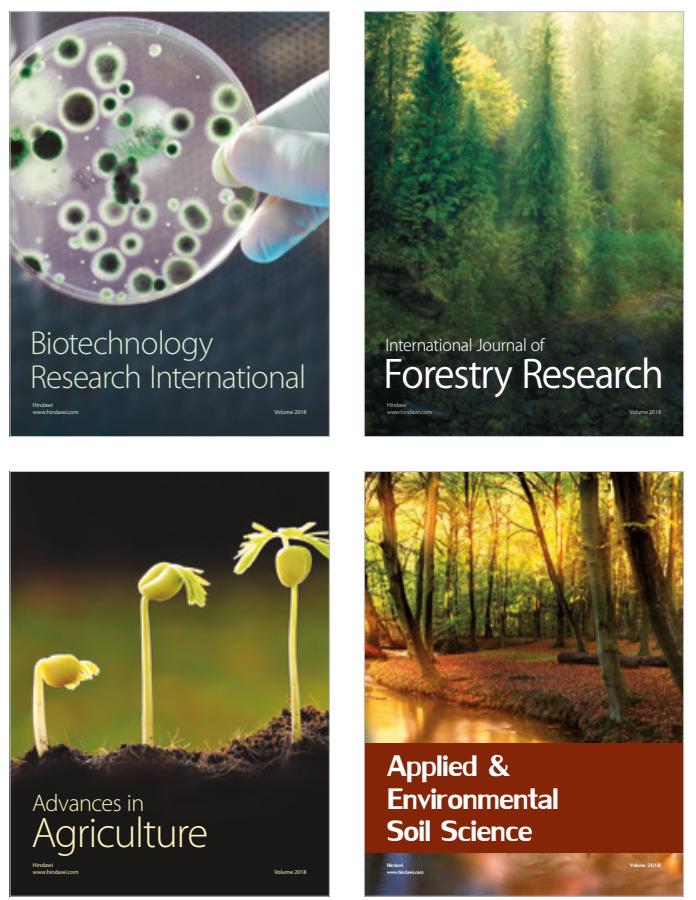

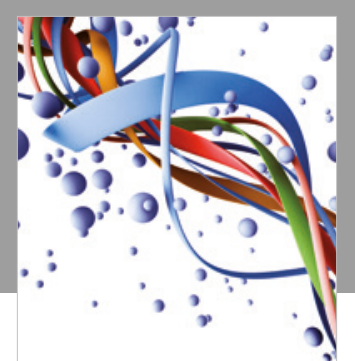

Scientifica

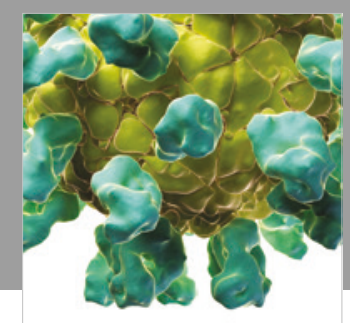

Veterinary Medicine International

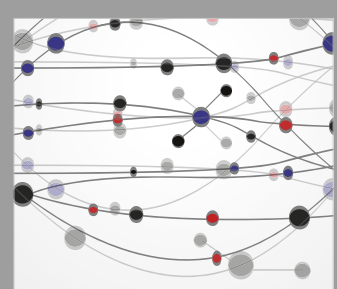

The Scientific World Journal
